\title{
Načelo traženja materijalne istine i upravni postupak
}

\section{Boris Ljubanović}

\author{
https://doi.org/10.31297/hkju.19.4.6 \\ UDK 340.132.6:35.077.2/3.01 \\ Review scientific paper / pregledni znanstveni rad \\ Received / primljeno: 30. 5. 2019. \\ Accepted / prihvaćeno: 15.11.2019.
}

Nakon konstatacije da su procesna načela kao opća pravna pravila činitelj jedinstva općih i posebnih upravnoprocesnih propisa te djelomičnog jedinstva sudskih i upravnog postupka, autor u radu zastupa stajalište da je načelo traženja materijalne istine znanstveno opravdano i prihvatljivo, ali ne u smislu klasične filozofske teorije istine, tzv. teorije korespondencije kao „potpune suglasnosti subjektivne spoznaje s objektivnom stvarnošću“, nego kao konstrukcija pravne teorije u značenju metode ili načina prikupljanja procesne građe i utvrđivanja činjeničnog stanja koje se shvaća kao činjenično stanje na kojem je legitimno utemeljiti odluku procesnog tijela. Rad sadržava definiciju načela traženja materijalne istine, obradu najvažnijih pravila našega upravnoga procesnog prava kojima je to načelo utemeljeno te pravila kojima je ono ograničeno. Slijedi razmatranje načela traženja materijalne istine u parnič-

* Prof. dr. sc. Boris Ljubanović, Pravni fakultet Sveučilišta Josip Juraj Strossmayer u Osijeku, Hrvatska (Full Professor, Faculty of Law, University Josip Juraj Strossmayer in Osijek, Croatia, e-mail: ljboris@pravos.hr).

ORCID ID: https://orcid.org/000-0003-3995-9991 
nom postupku te usporedba toga koliko to načelo vrijedi u upravnom postupku i parničnom postupku.

Ključne riječi: načelo, istina, materijalna istina, traženje istine, procesno tijelo, upravni postupak, parnični postupak

\section{Procesna načela kao faktor jedinstva općih i posebnih upravnoprocesnih propisa te djelomičnog jedinstva sudskih i upravnog postupka}

Bit će uskoro devedeset godina otkako je Ivo Krbek „bilješkama popratio" jugoslavenski Zakon o općem upravnom postupku iz 1930. koji je donesen po uzoru na austrijsku „veliku procesnu kodifikaciju“ iz $1925 .{ }^{1}$ On je pisao: „Prema dosadašnjem stanju bio je razmjerno vrlo mali broj upravno procesnih pitanja općenito reguliran za sve upravne stvari. Daleko više odredbi upravno procesne prirode sadržavali su pravni propisi po pojedinim upravnim stvarima. Tako su ovi propisi upravno procesne prirode $\mathrm{s}$ jedne strane odviše nabujali i izgubili preglednost, a s druge strane, općenito uzevši, bilo ih je opet premalo, pa su mnoga važna i potrebna procesna pitanja ostala neriješena. I kraj velike detaljnosti i specijalnosti, ostale su velike i vrlo fatalne praznine. Upravna praksa ispunjavala je ove praznine na razne načine: naročito što je primjenjivala procesne propise donešene za neku određenu upravnu stvar i na druge upravne stvari, što je presađivala naređenja sudskog procesa i na sam upravni postupak, i što je čak samostalno razvijala običajno pravo. Ukratko, da bi se razvila valjana i zakonita uprava, da bi se zaštitila pravna pozicija stranaka i ostalih učesnika u upravnom postupku i da bi se omogućila efikasna upravno sudska kontrola tog postupka, potrebno je da upravno procesni propisi budu i

${ }^{1}$ Austrija je prva kodificirala upravno procesno pravo „velikom procesnom kodifikacijom" iz 1925. koja je obuhvaćala četiri zakona: uvodni zakon, opći upravnopostupovni zakon, upravnokazneni zakon (s materijalnim i postupovnim propisima) i upravnoizvršni zakon. Zatim su, po uzoru na Austriju, opći upravni postupak normirale Čehoslovačka, Poljska te 1930. Jugoslavija. Zanimljivo je da se francuska teorija upravnog prava nije bavila upravnoprocesnim pitanjima. Ona se usmjerila na problematiku upravnog akta i njegovu moguću kontrolu u upravnosudskom postupku. Krbek cit. profesora Langrada prema kojem „... taj način tretiranja zavodi u bludnju, kao da pravna procedura postoji samo pred upravnim sudovima, a da je obrnuto pojedinac kod samih administrativnih vlasti razoružan“ (Krbek, 1950, str. 464, bilješka 1). 
točno zakonski normirani.“ Na taj je način, iznosio je Krbek: „U pogledu procesa postignuto ... na području cjelokupne uprave izvjesno pravno jedinstvo“ koje se „proteže i djelomično između sudskog i upravnog procesa“ jer premda „ZUP² vodi stalno račun o posebnim potrebama i osebinama upravnog postupka, a on opet zadržavajući u vidu ideju pravnog jedinstva - ne odstupa nepotrebno od načela sudskog postupka“ (Krbek, 1931, str. 4-6, 9-10).

Izložena gledišta profesora Krbeka iz prve polovice prošloga stoljeća aktualna su i prihvatljiva i u današnje vrijeme. Važan su činitelj jedinstva općih i posebnih upravnoprocesnih propisa te djelomičnog jedinstva sudskih i upravnog postupka procesna načela kao opća pravna pravila koja „vrijede za sve sporne slučajeve bez izuzetaka i čine temelj i za pravnu praksu i za teoriju" (Vrban, 2003, str. 406). Među tim je načelima i načelo traženja materijalne istine ili, kako se često naziva, načelo materijalne istine.

\section{Načelo traženja materijalne istine u pravnoj teoriji}

Načelo traženja materijalne istine konstrukcija je njemačke i austrijske pravne teorije XIX. stoljeća, u smislu istine do koje se dolazi primjenom slobodne ocjene dokaza ${ }^{3}$, s naglaskom na obrazloženje odluke i njezinu moguću kontrolu u postupku u povodu žalbe. To je načelo, po njemačko-austrijskom uzoru, u mnogim zemljama ne samo privuklo pozornost pravne literature, nego je postalo najvažnije procesno načelo. Različita su, međutim, stajališta o pojmu toga načela. Prema jednom je shvaćanju, podudarno tzv. teoriji adekvacije ili korespondencije ${ }^{4}$, ,istina suglasnost subjektivne spoznaje sa stvarnošću, (Krapac, 2014, str. 85, bilješka 6). Tako po piscu bivšeg SSSR-a Strogoviču „Materijalnom istinom ... naziva se puna saglasnost zaključaka pripremnog postupka i suda sa objektivnim činjenicama stvarnosti. Princip materijalne istine se izražava u zahtevu da

\footnotetext{
${ }^{2}$ ZUP je kratica za Zakon u općem upravnom postupku.

${ }^{3}$ Izraz materijalna istina prvotno je poslužio za označavanje bitne, neformalne istine do koje se dolazi slobodnom ocjenom dokaza, za razliku od formalne istine do koje se u prethodnom inkvizitornom postupku dolazilo primjenom tzv. legalne ocjene dokaza (za sistem legalne ocjene dokaza vidi Triva \& Dika, 2004, str. 164).

${ }^{4}$ Riječ je o klasičnoj teoriji istine koja potječe još od Aristotela. On je iznosio: „Pojmova pak nema izvan uma, izvan spoznaje. Istina je podudaranje pojma i stvari, tj. slaganje misli i stvari (adaequatio intellectus et rei)" (Kalin, 1991, str. 102).
} 
fakta, što su ih utvrdili pripremni postupak i sud, odgovaraju stvarnosti ..." (Strogovič , 1948, str. 57). ${ }^{5}$

Prema stajalištu Vasiljevića „(Z)ahtev za dobijanje istine o činjenicama u krivičnom postupku u najpotpunijoj mogućoj meri naziva se načelom istraživanja materijalne (ili realne, stvarne) istine" (Vasiljević, 1981, str. 319). Po Ogorelici „(P)od materijalnom, objektivnom ili realnom istinom razumijemo najveći stepen izvjesnosti do kojeg uopće može domašiti čovjek“ (Ogorelica, 1899, str. 425). Slično tome i prema Markoviću „(S) ubjektivna istina treba što je više moguće da se približi objektivnoj. Takva istina jeste materijalna istina. Pod materijalnom istinom razumemo najveći stepen izvesnosti do kojeg sudija može doći" (Marković, 1937, str. 198). ${ }^{6}$ Potonje definicije načela materijalne istine stavljaju naglasak na gledište koje prevladava u procesnoj teoriji, naime, da istina koja se utvrđuje u sudskim postupcima ima relativan karakter. Stoga su nazivi, osim materijalna, i subjektivna ili relativna istina. I prema Trivi „(A)rgumenti koji ukazuju na tek relativnu istinitost ljudskih spoznaja važe i za saznanja i spoznaje suda stečene u parničnom postupku“ (Triva \& Dika, 2004, str. $160)$ te Bayeru „(O)va konstatacija relativnog karaktera istine, do koje se dolazi u krivičnom postupku, znanstveno je potpuno opravdana i ne može se pobiti“ (Bayer, 1953, str. 651). Na relativnost istine koja se utvrđuje u postupcima, uključujući i upravni postupak, utječu i ograničenja u potrazi za istinom koja su predviđena procesnim propisima. ${ }^{7}$ Što se tiče upravnopravnih pisaca, oni drže da je odredbom čl. 8. ZUP-a prihvaćeno načelo materijalne istine u našemu upravnom postupku te u skladu s tim u definiciju toga načela unose formulaciju iz čl. 8. Tako Lilić, po kojemu načelo istine znači da se u postupku „moraju pravilno i potpuno utvrditi sve činjenice i okolnosti značajne za donošenje zakonitog i pravilnog rješenja (odlučne činjenice)" (Lilić, 2010, str. 414). Babac govori o načelu

${ }^{5}$ Strogovičevo bi načelo materijalne istine, iznosio je Bayer, „trebalo biti nekakva operativna direktiva organima krivičnog postupka“ koja „nije ništa drugo do suvišna parola ..." (Bayer, 1953, str. 654).

${ }^{6}$ Grubiša smatra da naziv materijalna istina nije nužan jer se izraz pravilno i potpuno utvrđeno činjenično stanje ne može drukčije shvatiti nego kao istina (Grubiša, 1980, str. 20).

${ }^{7}$ Damaška kaže: „Čak i kad aktivistička država ne bi prihvaćala vrijednosti koje ograničavaju potragu za istinom, pokušaj da se ostvari najveći mogući standard uspješnog dokazivanja stvarao bi neprihvatljive troškove u smislu odugovlačenja postupka i stvaranja raznih drugih problema ... državni interes ... može nametati da se neka činjenična hipoteza prihvati, iako je neka druga nešto vjerojatnija. Ako mogućnost pogreške na osnovi suprotstavljenih hipoteza nije jednako ozbiljna, oslanjanje na manje vjerojatnu, ali istodobno manje opasnu hipotezu, racionalni je odgovor na potrebu za akcijom u neizvjesnim uvjetima" (Damaška, 2008, str. 68). 
materijalne istine koje znači „(D)a se utvrdi sve ... okolnosti koje su važne za to da se donese rješenje koje udovoljava visokim zahtjevima zakonitosti i pravilnosti“ (Babac, 2004, str. 840). Prema Đerđi „(P)od materijalnom istinom podrazumijeva se potpuno i točno utvrđeno činjenično stanje koje je ujedino i podloga za donošenje rješenja“ (Đerđa, 2011, str. 17).

Znatno širi način gledanja na načelo materijalne istine potekao je od njemačkog autora Birkmeyera. I on je označavao materijalnu istinu kao suprotnost formalnoj istini, ali je dodao sljedeće: ,... dostizanju materijalne istine ... mora i zakon sa svoje strane odstraniti s puta sve zapreke ... princip materijalne istine traži da stranke ne smiju sucu zapriječiti put do istine svojom dispozicijom materijala koji on mora uzeti kao temelj svojoj presudi, nego i da sami propisi postupka ostave slobodan put do saznanja istine" (Birkmeyer, 1898, str. 81). Na izloženi način Birkmeyer je pitanje istine, s pravnog gledišta, sveo na procesnu metodu kojom se utvrđuju važne činjenice. Materijalna je ona istina koja se ostvaruje u postupku koji sadržava propise koji tijelu postupka osiguravaju slobodan put do saznanja istine, odnosno koji mu ne postavljaju prepreke na tom putu.

$\mathrm{Na}$ tragu toga shvaćanja, Bayer je dao definiciju načela traženja materijalne istine, a Triva je doslovno prenio tu njegovu definiciju kao „način postupanja iz kojega su isključene (negirane) sve štetne forme koje bi se inače, iz bilo kojeg razloga, nametale“, odnosno kao forme postupanja koje "moraju biti takve da osiguravaju, a ne smiju biti takve da ugrožavaju saznanje istine u postupku" (Triva \& Dika, 2004, str. 162). Na takav način formulirano načelo traženja materijalne istine, isticao je Bayer, adresirano je zakonodavcu, a ne tijelu postupka jer ono mora uvažavati sve forme postupanja predviđene zakonom (Bayer, 1995, str. 116).

Teorija o načelu traženja materijalne istine deklarira se u europskim kontinentalnim pravnim sustavima, dok se u državama common law tradicije odražava teorija konsenzusa (Weigend, 2013, str. 394-396). U navedenom sustavu naglasak se sa spoznajnih problema premješta na brigu o pridržavanju pravila koja normiraju bitku dvaju suprotstavljenih strana (Damaška, 1973, str. 581). Premda njemačka procesna teorija, u kojoj je, uz austrijsku procesnu teoriju, načelo traženja materijalne istine nastalo, i u novije vrijeme naglašava da je to načelo jedno od vladajućih načela (Roxin \& Schünemann, 2012, str. 101), njemački pravni pisci ističu kako je stranačkim sporazumijevanjem (plea bargaining) ostvarena „promjena paradigme" (Schünemann, 2009, str. 490). Njemačka je, naime, kao i mnoge druge europske države, pa i Hrvatska, prihvatila sporazumijevanje stranaka. 


\section{Definicija načela traženja materijalne istine $u$ upravnom postupku}

Polazeći od shvaćanja da je načelo traženja materijalne istine, kao proizvod pravne teorije, znanstveno opravdano i prihvatljivo, ali ne u smislu „pune suglasnosti subjektivne spoznaje s objektivnom stvarnošću“, nego u značenju metode postupanja kojom se dolazi do istinita (pravilna) utvrđivanja činjeničnog stanja koje se razumije kao činjenično stanje na kojem je legitimno osnovati odluku procesnog tijela, kao i od osobitosti da upravno procesno pravo, osim propisa kojima se ostvaruje načelo traženja materijalne istine, sadržava i propise koji se tomu načelu suprostavljaju jer ono nije apsolutno ni neograničeno, materijalnu istinu formuliramo kao istinu koja se utvrđuje u upravnom postupku koji načelno ne sadržava forme (pravila) koje sputavaju utvrđivanje istine. Dosljedno tomu, načelo traženja materijalne istine načelo je koje znači da upravno procesno pravo u pravilu ne prihvaća forme (pravila) koje ugrožavaju utvrđivanje istine. Vidimo da je u toj definiciji naglasak na neprihvaćanju forma postupanja koje bi otežavale saznanje istine, što je u tomu smislu opravdanje za naziv materijalna (neformalna) istina. Tako postavljena definicija načela traženja materijalne istine razlikuje se od definicije toga načela hrvatskih upravnopravnih pisaca. Oni, naime, smatraju da je načelo materijalne istine prihvaćeno pravilom iz čl. 8. ZUP-a te stoga, u skladu s formulacijom iz toga pravila, to načelo definiraju kao zahtjev da se u postupku moraju utvrditi sve činjenice koje su važne za donošenje zakonita i pravilna rješenja (v. supra pod 2.). A zapravo, u našem je upravnom postupku prihvaćeno načelo o kojem se govori zato što ZUP, u pravilu, ne sadržava pravila (forme) koja ugrožavaju utvrđivanje istine, a prihvaća pravila (forme) u kojima se to načelo ostvaruje. Rečeno je u pravilu jer ZUP, kao što će se dalje vidjeti, prihvaća i pravila koja otežavaju saznanje istine, što znači da načelo traženja materijalne istine u našemu upravnom postupku nema apsolutni primat. Brisanjem pravila iz čl. 8. ZUP-a ne bi se ništa bitno promijenilo, ali bi brisanjem pravila ZUP-a koja otvaraju put do saznanja istine načelo o kojem se ovdje govori prestalo vrijediti.

Načelo traženja materijalne istine u izloženom smislu odnosi se na zakonodavca, ali i na službenu osobu javnopravnog tijela jer ona ima ključnu ulogu u njegovoj primjeni. Triva i Dika s pravom naglašavaju: „... zakonodavčeva volja nije jedini faktor od kojega zavisi mogućnost saznanja i spoznaje istine. Poruka nije ... upravljena samo zakonodavcu već i sucu ... Zakonski okviri dovoljno su široki da i suca učine odgovornim za oživotvo- 
renje osnovnog zadatka“ (Triva \& Dika, 2004, str. 163). Može se zasigurno ustvrditi da velik utjecaj na saznanje istine o važnim činjenicama ima stručno znanje, iskustvo u utvrđivanju činjenica i razum procesnog tijela, kao i njegov odnos prema konkretnom slučaju i osobama koje sudjeluju u postupku.

Izrazom traženje materijalne istine naglasak se stavlja na metodu, način utvrđivanja činjeničnog stanja, na aktivnost u potrazi za istinom.

\section{Najvažnija pravila upravnoga procesnog prava kojima je prihvaćeno načelo traženja materijalne istine}

\subsection{Općenito}

Načelo traženja materijalne istine uvjetovano je pravilima kojima se ono ostvaruje. Među tim su pravilima i ona koja svojim sadržajem tome načelu daju prednost pred zaštitom nekih drugih društvenih vrijednosti. Tako je, primjerice, prihvaćeno pravilo po kojem je dopušteno u žalbi iznositi nove činjenice i dokaze, uz dužnost stranke da obrazloži zašto te činjenice i dokaze nije iznijela u prvostupanjskom postupku, iako je to pravilo u opreci s procesnom disciplinom i prikupljanjem procesne građe u postupku prvog stupnja.

\subsection{Pravila kojima je prihvaćeno načelo traženja materijalne istine}

4.2.1. U pravilu iz čl. 8. ZUP-a, naslov mu je Načelo utvrđivanja materijalne istine, stoji: „U postupku treba utvrditi pravo stanje stvari i u tu se svrhu moraju utvrditi sve činjenice i okolnosti koje su bitne za zakonito i pravilno rješavanje upravne stvari." Obično se smatra da je tim pravilom utemeljeno načelo traženja materijalne istine u našemu upravnom postupku. Takvo je mišljenje, međutim, pogrešno jer bi citirani propis bez ostalih pravila upravnog postupanja kojima se ostvaruje načelo traženja materijalne istine bio i ostao samo propagandni slogan. To je pravilo, u gotovo istovjetnom tekstu, sadržano u Zakonu o općem upravnom postupku bivše Jugoslavije iz 1956. Valjalo bi ga izmijeniti tako da glasi: „U postupku se moraju pravilno (istinito) i potpuno utvrditi činjenice koje su važne za zakonito rješavanje upravne stvari.“ 
4.2.2. Načelo traženja materijalne istine ostvaruje se pravilom iz čl. 9/2. ZUP-a koje određuje: „Koje će činjenice i okolnosti uzeti za dokazane, utvrđuje službena osoba slobodnom ocjenom, na temelju savjesne i brižljive ocjene svakog dokaza posebno i svih dokaza zajedno te na temelju rezultata cjelokupnog postupka." Tim je pravilom, u skladu s naslovom ispred čl. 9. (Načelo ... slobodne ocjene dokaza), postavljena slobodna ocjena dokaza. Ocjena dokaza slobodna je u smislu nevezanosti službene osobe za zakonska pravila o dokaznoj snazi (vrijednosti) nekog dokaza. Sloboda se ne odnosi na zakone logike, mišljenja i općega ljudskog iskustva, što mora doći do izražaja u obrazloženju rješenja. Kada bi ocjena dokaza bila apsolutno slobodna, onda bi žalba protiv prvostupanjskog rješenja zbog pogrešno ili nepotpuno utvrđena činjeničnog stanja bila nepotrebna.

4.2.3. Načelo traženja materijalne istine u pravnoj se literaturi često poistovjećuje $s$ istražnim ili inkvizitornim načelom po kojem je procesno tijelo ovlašteno samoinicijativno, neovisno o prijedlogu stranaka, prikupljati procesnu građu ${ }^{8}$, što ga čini odgovornim za pravilno (istinito) i potpuno utvrđivanje činjeničnog stanja. Istražno načelo prihvaćeno je u upravnom postupku pravilima prema kojima službena osoba utvrđuje sve činjenice i okolnosti bitne za rješavanje o upravnoj stvari (čl. 47/1. ZUP-a); službena će osoba odrediti izvođenje dokaza kad nađe da je to potrebno radi razjašnjenja stvari te upotpuniti činjenično stanje i izvoditi dokaze o činjenicama koje prije u postupku nisu bile iznesene ili još nisu utvrđene, a potrebne su radi utvrđivanja pravog stanja stvari (čl. 51/2. ZUP-a); službena osoba u postupku utvrđuje činjenično stanje svim sredstvima prikladnim za dokazivanje te s tom svrhom može pribaviti isprave, saslušati svjedoke, pribaviti nalaz i mišljenje vještaka, postavljati pitanja vještaku i tražiti objašnjenja o izloženom nalazu i mišljenju, obaviti očevid (čl. 51/ 2., čl. 66/4. ZUP-a).

4.2.4. Načelo traženja materijalne istine utemeljeno je pravilima koja dopuštaju iznošenje novih činjenica i novih dokaza, i to: u žalbi, s tim da je stranka dužna obrazložiti zašto te činjenice i dokaze nije iznijela tijekom prvostupanjskog postupka (čl. 108/2. ZUP-a); u prijedlogu za obnovu postupka u kojemu je doneseno rješenje protiv kojeg se ne može izjaviti žalba, ako se sazna za nove činjenice ili stekne mogućnost da se upotrijebe novi dokazi koji bi sami ili u vezi s već izvedenim i upotrijebljenim dokazima mogli dovesti do drukčijeg rješenja da su te činjenice odnosno dokazi bili izneseni, odnosno upotrijebljeni u prijašnjem postupku (čl. 123/1/1. ZUP-a).

${ }^{8}$ Procesnu građu obuhvaćaju činjenice, dokazi i pravna pravila. Istražno načelo odnosi se ponajprije na činjenice i dokaze. 
4.2.5. Načelo traženja materijalne istine prihvaćeno je pravilima prema kojima se rješenje može pobijati žalbom zbog pogrešna ili nepotpuno utvrđena činjeničnog stanja, što će, ako drugostupanjsko tijelo utvrdi da su u prvostupanjskom postupku činjenice nepotpuno ili pogrešno utvrđene ili da je izreka pobijanog rješenja nejasna ili je proturječna obrazloženju, dovesti do poništenja rješenja i rješavanja stvari od drugostupanjskog tijela (čl. 108/1., čl. 117/1/1-3. ZUP-a).

4.2.6. Načelo traženja materijalne istine prihvaćeno je pravilom po kojem drugostupanjsko tijelo ispituje zakonitost i ocjenjuje svrhovitost pobijanog rješenja u granicama zahtjeva iz žalbe, ali pri tome nije vezano žalbenim razlozima (čl. 115/1. ZUP-a).

\section{Najvažnija pravila upravnoga procesnog prava koja ograničavaju načelo traženja materijalne istine}

\subsection{Općenito}

Načelo traženja materijalne istine nema apsolutnu važnost, tako da bi sva druga procesna načela i sve druge društvene vrijednosti morale dati prednost tome načelu. Ono se ostvaruje zato što su predviđena ograničenja u traženju istine, u granicama koje su postavljene zakonom. ${ }^{9}$ Dika upućuje na pristupe novije austrijske doktrine (tzv. teorija uvjerenosti u vjerojatnost) koja polazi „od spoznaje da se činjenično stanje u građanskom postupku ne može nikada s apsolutnom sigurnošću utvrditi, da je i sudac čovjek s ograničenim ćutilnim sposobnostima opažanja i samo subjektivnim spoznajnim sposobnostima, što sve potencira okolnost da je u procesu redovito riječ o povijesnom činjeničnom stanju“" (Dika, 2015, str. 4-5). Bayer postavlja pitanje kako procesno tijelo može saznati jesu li činjenice koje je utvrdilo u skladu s objektivnom stvarnošću kada mu ta stvarnost iz nekoga drugog izvora nije poznata (Bayer, 1953, str. 653-654).

${ }^{9}$ Prema učenju Trive i Dike: „Kad bi načelo traženje istine bilo nepovredivo, ne bi bilo ekonomske žrtve koju ne bi bilo vrijedno podnijeti da se sazna istina; ne bi bilo kraja čekanju na istinitu pravdu; ne bi smjelo biti kraja mogućnostima pravnih lijekova sve dok god ima izgleda da se sazna istina, a nezakonitost ukloni. Nasuprot tome, granice ekonomskih mogućnosti brzo zaustavljaju težnje ka istini; strah od samopomoći prisiljava na napuštanje lagodne rezerve nekadašnjeg starorimskog suca koji je, brinući o svojoj savjesti, smio otkloniti pružanje zaštite kad mu stvar činjenično nije bila jasna (tzv. non liquet)" (Triva \& Dika, 2004, str. 167 - 168). 


\subsection{Načelo traženja materijalne istine ograničavaju osobito sljedeća pravila}

5.2.1. Prema procesnim pravilima o rješavanju upravne stvari bez provedbe ispitnog postupka, službena osoba može neposredno riješiti stvar u postupku koji je pokrenut: a) po službenoj dužnosti, ako je to nužno za poduzimanje hitnih mjera radi zaštite života i zdravlja ljudi ili imovine veće vrijednosti koje se ne mogu odgađati, ako je to u javnom interesu, a činjenice na kojima se rješenje temelji utvrđene su ili barem učinjene vjerojatnima (čl. 49/2. ZUP-a); b) na zahtjev stranke, kad je propisano da se stvar može riješiti na temelju činjenica ili okolnosti koje nisu potpuno dokazane ili se dokazima samo posredno utvrđuju pa su činjenice ili okolnosti učinjene vjerojatnima, a iz svih okolnosti slučaja proizlazi da se zahtjevu stranke može udovoljiti (čl. 50/2. ZUP-a). Prihvatljivo je Šikićevo mišljenje da postupak neposrednog rješavanja ne treba promatrati kao opće pravilo za rješavanje upravne stvari te da se i u slučajevima kada postoje uvjeti za neposredno rješavanje strankama mora, u skladu s čl. 30 . ZUP-a, omogućiti izjašnjavanje o svim činjenicama i pravnim pitanjima bitnima za rješavanje stvari uvijek kada se za tim pokazuje potreba (Šikić, 2010, str. 228-229).

5.2.2. Potraga za istinom ograničena je pravilom iz čl. 55/2. ZUP-a po kojem će, ako se prethodno pitanje odnosi na kazneno djelo, a nema mogućnosti za kazneni progon, službena osoba razmotriti i to pitanje. To je iznimka od pravila da službena osoba, kada se prethodno pitanje tiče kaznenog djela, rješenjem prekida postupak dok nadležni sud ne riješi to pitanje. Iako riječi razmotriti i riješiti nemaju isto značenje (Anić, 1994, str. 876), spomenuta iznimka ima svrhu samo ako službena osoba, ovisno o rezultatu razmatranja, ima ovlast donijeti odluku, pozitivnu ili negativnu, o postojanju kaznenog djela. U tom slučaju o postojanju kaznenog djela, kao prethodnom pitanju, ne odlučuje sud načinom postupanja u kaznenom postupku, nego službena osoba javnopravnog tijela, što je važna iznimka od načela traženja materijalne istine. ${ }^{10}$

5.2.3. Prema pravilima iz čl. 57. ZUP-a, u postupku u kojem sudjeluju dvije stranke ili više njih s protivnim interesima upravna se stvar potpuno ili o pojedinim spornim pitanjima može riješiti nagodbom. Tim se pravi-

${ }^{10}$ Riječ je o ograničenju potrage za istinom kojim se ugrožava i pravna sigurnost i zato ono nije prihvatljivo. 
lom odstupa od načela materijalne istine jer ima drugu svrhu (izbjegavanje ispitnog postupka, brže rješavanje spora, manji troškovi postupka), a ne utvrđivanje istine.

5.2.4. Po čl. 118/1. ZUP-a drugostupanjsko tijelo ne može izmijeniti prvostupanjsko rješenje na štetu stranke koja je izjavila žalbu. ${ }^{11}$ Tim je pravilom propisana tzv. zabrana reformationis in peius (zabrana izmjene nagore, uz pogoršavanje). Ta zabrana ograničava načelo traženja materijalne istine, a propisana je zato što jamči stranci slobodno izjavljivanje žalbe, bez strepnje da će drugostupanjsko rješenje biti za nju nepovoljnije od onoga protiv kojeg je podnijela žalbu.

\section{Usporedba važenja načela traženja materijalne istine u upravnom postupku i parničnom postupku}

Za prihvaćanje i ostvarivanje načela traženja materijalne istine najvažnija su procesna pravila koja rješavaju pitanje ovlasti (prava) za prikupljanje procesne građe. Naime, ima li procesno tijelo ovlast da na vlastitu inicijativu, neovisno o prijedlogu stranaka, prikuplja procesnu građu, što se naziva istražnim ili inkvizitornim načelom, ili tu ovlast imaju samostalno i samoinicijativno same stranke, a u tom je slučaju riječ o raspravnom načelu. U postupcima u kojima dominira istražno načelo, s aktivnom ulogom procesnog tijela u prikupljanju dokaza i utvrđivanju činjenica, postoje uvjeti za istinito (pravilno) utvrđivanje činjeničnog stanja te stoga i za ostvarivanje načela traženja materijalne istine. I obratno, u postupcima koji su građeni na dosljednoj primjeni raspravnog načela, u kojima je procesno tijelo uglavnom samo neutralni arbitar raspravljanja stranaka, spomenuti uvjeti ne postoje.

Vidjeli smo supra pod 5. da u upravnom postupku prevladava istražno načelo. U tomu je postupku službena osoba ovlaštena po službenoj dužnosti „svim sredstvima prikladnim za dokazivanje“ utvrđivati činjenično stanje i u tom cilju ima ovlast pribaviti isprave, saslušavati svjedoke, pribaviti nalaz i mišljenje vještaka, postavljati pitanja vještaku i tražiti objašnjenja

${ }^{11}$ Iznimno, drugostupanjsko tijelo može izmijeniti prvostupanjsko rješenje na štetu stranke koja je izjavila žalbu samo iz razloga zbog kojih bi to rješenje moglo oglasiti ništavim ili poništiti, ako nije drukčije propisano (čl. 118/2. ZUP-a). 
nakon što je on izložio svoj nalaz i mišljenje, zatražiti iskaz stranke. Istražno načelo odraz je oficijelnog načela po kojem se upravni postupak, osim na inicijativu (zahtjev) stranke, pokreće i po službenoj dužnosti kad je to propisano zakonom ili je nužno radi zaštite javnog interesa; ako je postupak pokrenut po službenoj dužnosti, a stranka nije u ostavljenom roku dostavila zatražene podatke, službena će osoba nastaviti postupak te riješiti upravnu stvar (čl. 40/1., čl. 42/1., čl. 47/5. ZUP-a). Zato što pravila prema kojima dominiraju istražno načelo i oficijelno načelo, kao i druga pravila u prilog utvrđivanju istine, nadilaze pravila koja ograničavaju mogućnost saznanja istine, prikazana supra pod 6., u našemu upravnom postupku vrijedi načelo traženja materijalne istine. ${ }^{12}$

Za razliku od upravnog postupka, u kojem dominira istražno načelo, u parničnom postupku u kojemu je, prije svega ostaloga, riječ o zaštiti privatnog, stranačkog interesa, prevladava raspravno načelo. U tome su postupku stranke dužne najkasnije na pripremnom ročištu iznijeti činjenice i predložiti dokaze na kojima temelje svoje zahtjeve ili pobijaju navode i dokaze protivnika. Sud je ovlašten utvrditi činjenice koje stranke nisu iznijele i izvesti dokaze koje stranke nisu predložile samo ako posumnja da stranke idu za tim da raspolažu zahtjevima kojima ne mogu raspolagati, ako zakonom nije drukčije određeno (čl. 7/1. i 2., čl. 219/1., čl. 299/1. ZPP-a)..$^{13}$ Sud može do zaključenja prethodnog postupka, kada ocijeni da je to svrhovito za pravilno rješenje spora, upozoriti stranke na njihovu dužnost iznošenja činjenica i predlaganja dokaza na kojima temelje svoj zahtjev ili pobijaju navode i dokaze protivnika, a osobito na potrebu iznošenja odlučnih činjenica i predlaganja određenih dokaza te iznijeti razloge zbog kojih smatra da je to potrebno (čl. 219/2. ZPP-a). Vezanost suda, u pravilu, za volju stranaka u odnosu na činjenice koje mu je dopušteno utvrđivati i dokaze koje smije izvoditi ograničava načelo traženja mate-

12 Snažne istražne ovlasti službene osobe, kao i ovlast da po službenoj dužnosti pokreće i dalje održava upravni postupak i riješi upravnu stvar, pružaju realnu mogućnost da ona bude pristrana i zainteresirana za ishod postupka. Valjalo bi, stoga, saznati stanje stvari u upravnoj praksi. Predmet istraživanja bili bi spisi pravomoćno dovršenih upravnih predmeta, s ciljem prikupljanja podataka iz promatranog uzorka o broju prihvaćenih i odbijenih dokaznih prijedloga stranaka, broju dokaza koje je službena osoba izvela na vlastitiu inicijativu, žalbama zbog toga što je dokaz izveden na inicijativu službene osobe i/ili što osobi koja je ispitana nisu postavljena relevantna pitanja te zato nisu utvrđene ili su pogrešno utvrđene okolnosti koje su važne za istinito (pravilno) i potpuno utvrđivanje važnih činjenica, broju iz tih razloga poništenih rješenja. Dobiveni podatci mogli bi dati odgovor na pitanje utječu li i koliko istražne i oficijelne ovlasti službenih osoba negativno utječu na njihovu objektivnost i nepristranost. No to je posebna tema koja ostaje za neki budući rad.

${ }^{13}$ ZPP je kratica za Zakon o parničnom postupku. 
rijalne istine. No i druga pravila parničnoga procesnog prava otežavaju saznanje istine. Mogu se, uglavnom, svrstati u daljnje skupine. $U$ jednu pripadaju pravila po kojima stranke nemaju pravo iznositi nove činjenice i predlagati nove dokaze: a) u žalbi, osim ako se odnose na bitne povrede odredaba parničnog postupka zbog kojih se žalba može izjaviti, b) u reviziji, osim one iz čl. 382/1., i to samo ako se odnose na bitne povrede odredaba parničnog postupka zbog kojih se revizija može podnijeti, c) u prijedlogu za ponavljanje postupka, osim ako ih podnositelj prijedloga bez svoje krivnje nije mogao iznijeti prije nego što je prijašnji postupak pravomoćno završen (čl. 252/1., čl. 387., čl. 422/2. ZPP-a). Drugu skupinu čine pravila prema kojima se presuda zbog ogluhe i presuda zbog izostanka, a u pravilu ni presuda na temelju priznanja i presuda na temelju odricanja ne mogu pobijati žalbom zbog pogrešno ili nepotpuno utvrđenog činjeničnog stanja (čl. 353/2-4., čl. 467/1. ZPP-a).

Parnično procesno pravo sadržava i pravila kojima se ostvaruje načelo traženja materijalne istine. Osobito su to sljedeća pravila: sud je svakoj stranci dužan pružiti mogućnost izjašnjavanja o zahtjevima i navodima protivne stranke (čl. 5/1. ZPP-a); koje će činjenice uzeti kao dokazane odlučuje sud prema svom uvjerenju na temelju savjesne i brižljive ocjene svakog dokaza zasebno i svih dokaza zajedno, a i na temelju rezultata cjelokupnog postupka (čl. 8. ZPP-a) ${ }^{14}$; stranke i umješači dužni su na sudu govoriti istinu i savjesno se koristiti pravima koja su im priznata ovim zakonom (čl. 9. ZPPa); sudac pojedinac odnosno predsjednik vijeća rukovodi glavnom raspravom, ispituje stranke i izvodi dokaze (čl. 311/1. ZPP-a); dužnost je sudca pojedinca odnosno predsjednika vijeća brinuti se za svestrano raspravljanje predmeta spora (čl. 311/2. ZPP-a); presuda se može pobijati žalbom zbog ili pogrešno ili nepotpuno utvrđenog činjeničnog stanja (čl. 353/1. ZPP-a).

Iz izloženog je vidljivo da brojna pravila parničnoga procesnog prava koja svojim sadržajem višestruko ograničavaju načelo traženja materijalne istine, a osobito su to ona iz kojih proizlazi dominacija raspravnog načela kao posljedica načela dispozicije stranaka, nadmašuju pravila toga prava kojima se to načelo ostvaruje. Uzimajući to u obzir, može se konstatirati da je načelo traženja materijalne istine u parničnom postupku, za razliku od upravnog postupka, znatno manje izraženo. Može se reći da je ono u biti ograničeno jer ograničenja toga načela „suštinske su naravi“ (Triva \& Dika, 2004, str. 168). ${ }^{15}$

\footnotetext{
${ }^{14}$ Za slobodnu ocjenu dokaza koja je propisana tim pravilom v. supra 5.2.2.

15 Triva i Dika s razlogom iznose kako „se u parničnom postupku istina, i kad je shvaćena u relativnom smislu, ne može uvijek ostvariti“ (Triva \& Dika, 2004, str. 167).
} 


\section{Zaključak}

Načelo traženja materijalne istine konstrukcija je njemačke i austrijske procesne teorije XIX. stoljeća u smislu istine o važnim činjenicama koja se utvrđuje slobodnom ocjenom dokaza, što znači da procesno tijelo kod ocjene izvedenih dokaza nije vezano nikakvim propisima u dokaznoj snazi (vrijednosti) nekog dokaza, s tim da je dužno obrazložiti svoju odluku i na taj način omogućiti kontrolu činjeničnih zaključaka u postupku u povodu žalbe. To je načelo u mnogim zemljama po uzoru na njemačko i austrijsko pravo postalo najvažnije procesno načelo, ali uz različita tumačenja pojma toga načela.

$\mathrm{S}$ obzirom na različita ograničenja u potrazi za istinom koja su predviđena procesnim pravilima, uključujući i pravila upravnog postupka, nije se moguće složiti s onim autorima koji, podudarno klasičnoj filozofskoj teoriji istine, tzv. korespondencijskoj teoriji, načelo materijalne istine tumače kao „potpunu suglasnost subjektivne spoznaje s objektivnom stvarnošću“. Načelo traženja materijalne istine, kao proizvod pravne teorije, znanstveno je opravdano i prihvatljivo u značenju metode, načina ili forma (pravila) postupanja koji pružaju mogućnost istinita (pravilna) utvrđivanja činjeničnog stanja, koje se razumije kao činjenično stanje na kojem procesno tijelo legitimno utemeljuje svoju odluku. Izrazom traženje istine želi se istaknuti da je riječ o metodi ili načinu utvrđivanja činjeničnog stanja, o aktivnosti u potrazi za istinom.

Zato što u skladu s istražnim načelom i oficijelnim načelom službena osoba ima snažne istražne ovlasti i ovlast da u propisanim slučajevima po službenoj dužnosti pokrene i dalje održava upravni postupak te riješi upravnu stvar, a zatim i što su prihvaćena i druga pravila koja omogućuju saznanje istine, u našemu upravnom postupku vrijedi načelo traženja materijalne istine. No budući da su prihvaćena i procesna pravila koja ograničavaju potragu za istinom jer ona nema apsolutnu prednost, načelo traženja materijalne istine ostvaruje se u granicama koje određuju zakon.

U parničnom postupku dominiraju raspravno načelo i načelo dispozicije stranaka. Suglasno tim načelima sud je vezan za volju stranaka, i u pravilu u pogledu činjenica koje smije utvrđivati i dokaza koje smije izvoditi, i u odnosu na pokretanje parnice i njezino održavanje u tijeku. Uz to su prihvaćena i druga procesna pravila koja ugrožavaju saznanje istine. Odmjeravanjem svih tih brojnih pravila parničnoga procesnog prava koja svojim sadržajem sputavaju i onih manje brojnih koja omogućavaju istinito (pravilno) utvrđivanje činjeničnog stanja dolazimo do konstatacije da je načelo traženja materijalne istine u parničnom postupku, za razliku od upravnog postupka, u biti ograničeno. 


\section{Literatura}

Anić, V. (1994). Rječnik brvatskoga jezika. Drugo dopunjeno izdanje. Zagreb, Hrvatska: Novi Liber.

Babac, B. (2004). Upravno pravo, Odabrana poglavlja iz teorije i praxisa. Osijek, Hrvatska: Sveučilište J. J. Strossmayera u Osijeku, Pravni fakultet Osijek.

Bayer, V. (1953). Načelo traženja materijalne istine i naš novi Zakonik o krivičnom postupku. Naša zakonitost, 12, 649-657.

Bayer, V. (1995). Kazneno procesno pravo - odabrana poglavlja, Knjiga I, Uvod u teoriju kaznenog procesnog prava. Zagreb, Hrvatska: Ministarstvo unutarnjih poslova Republike Hrvatske.

Birkmeyer, K. (1898). Deutsches Strafprozessrecht [Njemački zakon o kaznenom postupku]. Berlin, Njemačka.

Damaška, M. (1973). Evidentiary barriers to conviction and two models of criminal procedure: a comparative study [Evidencijske prepreke osudi i dva modela kaznenog postupka: komparativni studij]. University of Pennsylvania Law Review, 121(3), 506-589.

Damaška, M. (2008). Lica pravosuda i državna vlast, Usporedni prikaz pravosudnih sustava. Zagreb, Hrvatska: Nakladni zavod Globus, https://doi. org/10.2307/3311301

Đerđa, D. (2011). Upravni postupak. Rijeka, Hrvatska: Veleučilište u Rijeci.

Dika, M. (2015). O standardima utvrđenosti činjenica u parničnom postupku. Zbornik Pravnog fakulteta Sveučilišta u Rijeci, 36(1), 1, 1-70.

Grubiša, M. (1980). Činjenično stanje u krivičnom postupku. Drugo dopunjeno i izmijenjeno izdanje. Zagreb, Hrvatska: Informator.

Kalin, B. (1991). Povijest filozofije. Zagreb, Hrvatska: Školska knjiga.

Krapac, D. (2014). Kazneno procesno pravo, Prva knjiga: Institucije, VI. izmijenjeno i dopunjeno izdanje. Zagreb, Hrvatska: Narodne novine.

Krbek, I. (1931). Zakon o općem upravnom postupku. Zagreb, Hrvatska: „Obnova“.

Krbek, I. (1950). Osnovi upravnog prava FNRJ. Zagreb, Hrvatska: Izdavački zavod Jugoslavenske akademije znanosti i umjetnosti.

Lilić, S. (2010). Upravno pravo, Upravno procesno pravo. Četvrto izmenjeno i dopunjeno izdanje. Beograd, Srbija.

Marković, B. (1937). Udžbenik sudskog krivičnog postupka Kraljevine Jugoslavije. Drugo popravljeno i dopunjeno izdanje. Beograd, Srbija.

Ogorelica, N. (1899). Kazneno procesualno pravo. Zagreb, Hrvatska.

Roxin, C., \& Schünemann, B. (2012). Strafverfabrenrecht [Kazneno procesno pravo]. Munchen, Njemačka: C. H. Beck.

Schünemann, B. (2009). Risse im Fundament, Flammen im Gebälk: Die Strafprozessordnung nach 130 Jahren [Pukotine u temeljima, plamen u gredama: Zakonik o kaznenom postupku]. Zeitschrift für Internationale Strafrechtsdogmatik, 5(10), 484-494. 
Strogovič, M. S. (1948). Krivični sudski postupak. Beograd, Srbija.

Šikić, M. (2010). Neposredno rješavanje prema novom Zakonu o općem upravnom postupku. Zbornik Pravnog fakulteta Sveučilišta u Rijeci, 31(1), Suppl., 219-230.

Triva, S., \& Dika, M. (2004). Građansko parnično procesno pravo. VII. izmijenjeno i dopunjeno izdanje. Zagreb, Hrvatska: Narodne novine.

Vasiljević, T. (1981). Sistem krivičnog procesnog prava SFRJ. Treće izmenjeno i dopunjeno izdanje, Beograd, Srbija.

Vrban, D. (2003). Država i pravo. Zagreb, Hrvatska: Golden marketing.

\section{Pravni izvori}

Zakon o općem upravnom postupku, NN 47/09

Zakon o parničnom postupku, Službeni list SFRJ, 4/77, 36/77, 6/80, 36/80, 69/82, 43/82, 58/84, 74/87, 57/89, 20/90, 27/90, 35/91

Zakon o parničnom postupku, NN 53/91, 91/92, 112/99, 129/00, 88/01, 117/03, $88 / 05,2 / 07,96 / 08,84 / 08,123 / 08,57 / 11,25 / 13,89 / 14$ 


\section{THE PRINCIPLE OF MATERIAL TRUTH AND ADMINISTRATIVE PROCEDURE}

\section{Summary}

The principle of searching for material truth, as a product of legal theory, is scientifically justified and acceptable as a method and form (rule) of action to enable true (correct) fact finding; which is the ground upon which the authority legitimately bases its decision. The term truth-seeking emphasizes the methodology or way of establishing a factual situation; i.e., an activity in search of truth. In accordance with the investigative and official principles of the Croatian legal system, an official person deciding in a single case has strong investigative powers and the authority to initiate and decide in single administrative proceedings ex officio; making the principle of searching for material truth an important one. Although the legal system adopts rules and procedures to enable truth seeking, other procedural rules restrict the pursuit of truth, confining the principle of searching for material truth within the limits set by the law. For example, the civil process is dominated by the principle of debate and the disposition of the parties. In accordance with these principles, the court is bound by the will of the parties, both as to the established facts and adduced evidence, as well as with regard to the initiation and maintenance of the litigation. Other procedural rules that threaten the knowledge of truth are also accepted. Taking into consideration the numerous rules of civil procedure law that impede real truth seeking and those less numerous allowing for a true (correct) determination of the facts, it may be concluded that unlike administrative proceedings, the principle of seeking material truth in civil proceedings is substantially restricted.

Keywords: principle, truth, substantive truth, search for truth, procedural authority, administrative procedure, civil proceedings 